\title{
Parliamentary Representation in Modern Britain: Past, Present, and Future
}

\author{
Miles Taylor
}

Großbritannien-Zentrum/Centre for British Studies, Humboldt-Universität zu Berlin, 10117 Berlin, Germany

Email: miles.taylor@hu-berlin.de

\begin{abstract}
A series of recent books all attest to a revival of interest in the theory and practice of parliamentary representation in the modern era as a scholarly discipline. This review surveys eight different aspects of that history since the early nineteenth century: the spatial dimension of the Palace of Westminster; the comparative framework offered by the history of parliaments in Europe; ideas of parliamentary representation; the history of parliamentary procedure; women in parliament; the House of Lords; the history of corruption; and the Brexit crisis. Insights and perspectives are drawn from recent historical research as well as from political science and intellectual history. The review concludes by observing that the history of parliamentary representation in the modern era is in good shape. Some older interpretive paradigms still lurk, especially an obsession with 'democratization'. However, more is now known about individual MPs and constituencies than ever before. The digitization of the records of parliament is expediting the kind of longitudinal analysis which was impossible back in the 1960s and 1970s. And the intellectual history and public policy literature around the idea of representation is enjoying a renaissance.
\end{abstract}

The new parliament of the United Kingdom that assembled at Westminster on 17 December 2019 was a departure from the old in several respects. At its opening, the monarch dispensed with the ceremonial state coach, arriving by car for the occasion. There were more women MPs than ever before -34 per cent compared to less than 5 per cent thirty-five years ago. A new Speaker, Sir Lindsay Hoyle, presided over the House of Commons, promising 'humour and quiet words' in place of his abrasive predecessor. Over in the House of Lords, the benches were full to the brim, the upper chamber now at its largest since its culling by Tony Blair's government in 1999. This was also the 'get Brexit done' parliament. The general election of the previous week had settled the great issue of contemporary British politics seemingly

(C) The Author(s), 2021. Published by Cambridge University Press. This is an Open Access article, distributed under the terms of the Creative Commons Attribution licence (http://creativecommons.org/licenses/by/4.0/), which permits unrestricted re-use, distribution and reproduction, provided the original article is properly cited. 
once and for all, ejecting almost 25 per cent of sitting MPs in the process. ${ }^{1}$ One of the new parliament's first acts a few weeks later was to pass the Withdrawal Agreement Bill, giving effect to the 'leave' vote of the 2016 referendum on UK membership of the European Union. So, as MPs settled into Westminster, their European counterparts - seventy-two UK MEPs - waved goodbye to Brussels. The cord (some would say the chain) that had linked the British to Europe since 1979 was finally cut. As it turned out, this new parliament did not last long in its conventional form. After only forty-five days of sitting it was locked down by the COVID-19 pandemic. From 21 April 2020, it was reduced to a chamber abiding by rules of 'social distancing', as short and as rump a parliament as its more famous ancestors. When it returns to normal, more disruption may follow. Both the Commons and the Lords are scheduled to move to separate temporary accommodation as part of the $£ 4 \mathrm{bn}$ renovation project envisaged for the Palace of Westminster.

At such a turning point in the history of parliament - its present confused and its future uncertain - it is worth reaching into the past to identify some of the wider historical contexts into which the current turbulence might be placed. In different ways, a series of recent publications all attest to a revival of interest in the theory and practice of parliamentary representation in the modern era as a scholarly discipline. ${ }^{2}$ Until lately, the subject lacked coherence. Scholarship has centred around three distinct traditions - the biographical, the theoretical, and the scientific. They have seldom been in dialogue. In the first place, there is the prosopographical approach, exemplified by the research of The history of parliament, which started out in the 1930s and which so far has published sixty volumes in fourteen sections ranging from the fourteenth to the early nineteenth centuries. Here, the concept of biography stretches to include the lives of constituencies as well as MPs and peers, making for a gargantuan project sometimes criticized for missing the wood for the trees. ${ }^{3}$ In the last decade, this tendency has begun to be corrected, with longer survey volumes emerging from The history, and more

\footnotetext{
${ }^{1}$ Including those who stood down before the election: Ian Brunskill, ed., The Times guide to the House of Commons 2019 (London, 2020), pp. 59-60.

${ }^{2}$ This review takes the following works as its starting point: Remieg Aerts et al., eds., The ideal of parliament in Europe since 1800 (London, 2019); Andrew Blick, Stretching the constitution: the Brexit shock in historic perspective (Oxford, 2019); Gregory Conti, Parliament the mirror of the nation: representation, deliberation, and democracy in Victorian Britain (Cambridge, 2019); Emma Crewe and Andrew Walker, An extraordinary scandal: the Westminster expenses crisis and why it still matters (London, 2019); Paul Evans, ed., Essays on the history of parliamentary procedure in honour of Thomas Erskine May (Oxford, 2017); Edward Gillin, The Victorian palace of science: scientific knowledge and the building of the Houses of Parliament (Cambridge, 2017); Michael Koß, Parliaments in time: the evolution of legislative democracy in Western Europe, 1866-2015 (Oxford, 2019); Philip Norton, Reform of the House of Lords (Manchester, 2017); Matt Qvortrup, The referendum and other essays on constitutional politics (Oxford, 2019); Rachel Reeves, Women of Westminster: the MPs who changed politics (London, 2019).

${ }^{3}$ For the history of The history, see David Cannadine, 'The history of parliament: past, present - and future', Parliamentary History, 26 (2007), pp. 366-86. For criticism, see Martin Daunton, 'Virtual representation: the history of parliament on CD-Rom', Past \& Present, 167 (2000), pp. 238-61.
} 
attention being paid to the modern period. ${ }^{4}$ Still, the steady but protracted progress of The history has left a vacuum, only filled from time to time by breezy anecdotal histories of parliament. ${ }^{5}$

Political theory has also been influential in the history of parliamentary representation. Scholars still routinely acknowledge several pioneering works from the late 1960s and 1970s on the idea of representative democracy. ${ }^{6}$ These studies focused on the intellectual canon of the seventeenth and eighteenth centuries - Thomas Hobbes, John Locke, Jean-Jacques Rousseau, the Abbé Sieyès, and the American founding fathers - observing a divergence between direct democracy (America, France) and indirect representation (Britain). Although there was some acknowledgement of later theorists, for example Alexis de Tocqueville, John Stuart Mill, and Max Weber, these classic studies of representation were rooted in pre-modern history, exploring a series of texts that themselves were often obsessed with the working of democracy in antiquity. The lacunae here are obvious. Modern systems of parliamentary representation came after the golden age of democratic theory. Although a new wave of work has emerged in the last twenty years, centred on a reappraisal of the claims of democracy, much of it remains rooted in the

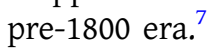

A third perspective on parliamentary representation comes from political science and public policy studies. Growing out of the post-war 'Nuffield' election surveys and their successors, as well as the vogue for comparative research on government that flourished in the 1960s, British social scientists produced a series of descriptive studies of elections, the electorate, and pressure groups. ${ }^{8}$ In the 1980 s and 1990s, this field became increasingly

\footnotetext{
${ }^{4}$ The story of parliament: celebrating 750 years of parliament in Britain (London, 2015); Clyve Jones, ed., A short history of parliament (Woodbridge, 2009). This was not officially a History of Parliament publication, but it featured many of its researchers. For the 1832-68 section: www.historyofparliamentonline.org/about/latest-research/1832-1868. For twentieth-century coverage: Emma Peplow and Priscila Pivatto, eds., The political lives of postwar British MPs: an oral history of parliament (London, 2020).

${ }^{5}$ Christopher Jones, The great palace: the story of parliament (London, 1983); John Field, The story of parliament in the Palace of Westminster (London, 2002); Chris Bryant, Parliament: the biography (2 vols., London, 2014-15). See also Paul Seaward, 'Why the history of parliament has not been written', Parliamentary History, 40 (2021), pp. 5-24.

${ }^{6}$ Hanna Pitkin, The concept of representation (Berkeley, CA, 1967); A. H. Birch, Representation (London, 1971); Carole Pateman, The problem of political obligation: a critique of liberal theory (London, 1979).

${ }^{7}$ Bernard Manin, The principles of representative government (Cambridge, 1997); Ian Shapiro et al., eds., Political representation (Cambridge, 2009); Philip Pettit, On the people's terms: a republican theory and model of democracy (Cambridge, 2012); Nadia Urbinati, Representative democracy: principles and genealogy (Chicago, IL, 2006); Mónica Brito Vieira and David Runciman, Representation (Cambridge, 2008); Richard Bourke and Quentin Skinner, eds., Popular sovereignty in historical perspective (Cambridge, 2016); William Selinger, Parliamentarism: from Burke to Weber (Cambridge, 2019). David Judge's Representation: theory and practice in Britain (London, 1999) remains one of the few works that situates the theory in a more modern context.

${ }^{8}$ David Butler, The electoral system in Britain: 1918-1951 (Oxford, 1953); S. E. Finer, Anonymous empire: a study of the lobby in Great Britain (London, 1958); Frank Bealey et al., Constituency politics: a study of Newcastle-under-Lyme (London, 1965).
} 
quantitative, taking its cue from the school of American 'legislative studies', now focused more on dynamics inside parliament, in particular, MPs' recruitment and careers, their constituency service, and the machinery of legislation. ${ }^{9}$ At first glance, this methodology seems unfamiliar territory for the historian. Political scientists and public policy scholars tend to be presentist. However, in recent years they have turned back to history. New historic data on division lists, political corruption, MPs' backgrounds, and legislative outcomes have extended the chronological reach of legislative studies. ${ }^{10}$ Additionally, the digitization of parliamentary records, including Hansard (the parliamentary debates) and the journals of the House of Commons, is expanding the possibilities of text mining and other forms of longitudinal research. ${ }^{11}$ At the same time, the era of constitutional reform unleashed by Tony Blair's first administration of 1997-2001 pushed public policy research into deeper historical and comparative study, most notably with the creation of the Constitution Unit at University College London in $1996 .{ }^{12}$ Consequently, much of the current thinking on the present and future of parliament is situated within a more historical context, a move paralleled by a substantial increase in historical briefing papers and statistics prepared by parliament's own information services. ${ }^{13}$

This historical turn in political science and public policy, the resumption of interest in the political theory of representative democracy, and a leap forward into modernity by The history of parliament all bode well for the study of parliamentary representation. It is now easier to connect past and present. One institution that has benefited from this shift is the Palace of Westminster itself.

\footnotetext{
${ }^{9}$ Bruce Cain et al., The personal vote: constituency service and electoral independence (Cambridge, MA, 1987); Donald D. Searing, Westminster's world: understanding political roles (Cambridge, MA, 1994); Pippa Norris and Joni Lovenduski, Political recruitment: gender, race, and class in the British parliament (Cambridge, 1995).

${ }^{10}$ Andrew Eggers (with Arthur Spirling), 'Guarding the guardians: partisanship, corruption and delegation in Victorian Britain', Quarterly Journal of Political Science, 9 (2014), pp. 337-70; Arthur Spirling, 'British political development: a research agenda', Legislative Studies Quarterly, 39 (2014), pp. 435-7; Christopher J. Kam, Party discipline and parliamentary politics (Cambridge, 2009); Alexandra Kelso, 'The politics of parliamentary procedure: an analysis of Queen's Speech debates in the House of Commons', British Politics, 12 (2017), pp. 267-88.

${ }^{11}$ For parliamentary debates, see Hansard Corpus: British Parliament (University of Glasgow et al., 2014-16), www.english-corpora.org/hansard/; Digging into Linked Parliamentary Data (DiLiPaD) (Institute of Historical Research, University of London, 2014-16), https://repository.jisc.ac.uk/ 6544/1/DiLiPaD_final_report_1.pdf; Christian Rauh and Jan Schwalbach, The Parlspeech V2 data set: full-text corpora of 6.3 million parliamentary speeches in the key legislative chambers of nine representative democracies (January 2020), https://doi.org/10.7910/DVN/L4OAKN/C2TWCZ, Harvard Dataverse, V1. The research potential of the Commons journal has received less coverage, partly because the interface is less user-friendly: https://publications.parliament.uk/pa/cm/cmjournal.htm.

${ }^{12}$ https://www.ucl.ac.uk/constitution-unit/about-constitution-unit Meg Russell's research on the House of Lords, and Alan Renwick's on electoral systems exemplify the Unit's historically grounded approach: Russell, Reforming the House of Lords: lessons from overseas (Oxford, 2000); Renwick, The politics of electoral reform: changing the rules of democracy (Cambridge, 2011).

${ }^{13} \mathrm{https}: / /$ researchbriefings.parliament.uk.
} 
Usually the preserve of architectural and art historians, and well served by volumes destined for the coffee-table, the history of the home of parliament over seven centuries has been transformed by new inter-disciplinary research. ${ }^{14}$ We now know much more about the changing conglomeration of buildings and spaces that have occupied the site since the thirteenth century. This improved understanding of the form of parliament is enhancing awareness of its functions, not least those of the House of Commons, which moved into St Stephen's Chapel in 1548. New work on parliamentary ceremonial and procedure, on MPs' behaviour, even on the sensory atmosphere of the debating chamber, are among the first fruits to fall from this new branch of study. ${ }^{15}$

For the modern historian, analysis of the Palace of Westminster is dominated by the reconstruction undertaken by Charles Barry following the fire of 1834. Historians have always been fascinated by how Barry on the outside, and Augustus Pugin within, sought to instil a sense of continuity with the past in the new buildings, reconnecting the Palace with its medieval English origins, and ensuring that it continued to embody the mixed constitution in miniature, the Lords and Commons side by side, with a separate entrance and set of chambers reserved for the monarch. ${ }^{16}$ Alongside this reinvention of tradition went some more practical considerations. By the 1820s, the business of parliament had outgrown its buildings. The addition of 100 Irish MPs from 1801 and oversight of a colonial empire that expanded from thirty to forty-five territories by the end of the Napoleonic Wars in 1815, together with an exponential increase in local 'improvement' bills, as the British economy was transformed by the growth of commerce and industry, left parliament unfit for purpose as the national legislature. ${ }^{17}$ In the years before the fire of 1834 , there were several

\footnotetext{
${ }^{14}$ Warwick Rodwell and Tim Tatton Brown, eds., Westminster: the art, architecture and archaeology of the Royal Abbey and Palace (2 vols., Leeds, 2015); J. P. D. Cooper and Richard Gaunt, eds., Space and sound in the British parliament, 1399 to the present: architecture, access and acoustics, special issue, Parliamentary History, 38 (2019). See also www.virtualststephens.org.uk/about. Amongst older studies of the Palace, see: M. H. Port, The Houses of Parliament (New Haven, CT, 1976); Robert Cooke, The Palace of Westminster: Houses of Parliament (London, 1987); Christine Riding and Jacqueline Riding, eds., The Houses of Parliament: history, art and architecture (London, 2000).

${ }^{15}$ See the essays in Cooper and Gaunt, eds., Space and sound in the British parliament; Paul Seaward, 'Parliament observed: the gallery of the old House of Commons', in Elaine Chalus and Perry Gauci, eds., Revisiting the polite and commercial people: essays in Georgian politics, society, and culture in honour of Professor Paul Langford (Oxford, 2019), pp. 59-76.

${ }^{16}$ Port, The Houses of Parliament; W. J. Rorabaugh, 'Politics and the architectural competition for the Houses of Parliament, 1834-1837', Victorian Studies, 17 (1973), pp. 155-75; Roland Quinault, 'Westminster and the Victorian constitution', Transactions of the Royal Historical Society, 6th ser., 2 (1992), pp. 79-104. Caroline Shenton's recent paired volumes provide a definitive guide to the destruction of the old and the building of the new Palace: The day parliament burned down (Oxford, 2012); Mr Barry's war: rebuilding the Houses of Parliament after the great fire of 1834 (Oxford, 2016).

${ }^{17}$ Peter Jupp, British politics on the eve of reform: the duke of Wellington's administration, 1828-1830 (Basingstoke, 1998), chs. 5-6; Joanna Innes, 'Legislating for three kingdoms: how the Westminster parliament legislated for England, Scotland and Ireland, 1707-1830', in Julian Hoppit, ed., Parliaments, nations and identities in Britain and Ireland, 1660-1850 (Manchester, 2003), pp. 15-47; Miles Taylor, 'Colonial representation at Westminster, c. 1800-1865', in ibid., pp. 206-30.
} 
enquiries into how the Palace might be replaced by a legislature suited for a modern empire. ${ }^{18}$

As much as Barry's and Pugin's designs invoked olden times, the building was replete with new technology, as Edward Gillin's closely researched monograph makes clear. Other historians have shown how experiments with ventilation and time management began in the temporary House of Commons, where MPs met between 1835 and $1851 .{ }^{19}$ But it was the new Lords and Commons chambers that became an intensive 'laboratory' for trying out cutting-edge innovations in light, sound, and stone. The Victorian palace of science describes how Barry consulted with leading scientists of the day, such as Michael Faraday and George Airy (the Astronomer Royal); how he sought untried materials (cast iron and Anston stone from Yorkshire rather than the Portland variety beloved by most London architects); how he employed David Reid to overhaul the ventilation of the Palace, and allowed Goldsworthy Gurney to trial 'Bude' oil lamps. Ornamental did not mean impractical. The first of the new Palace's ornate steeples to go up was actually a ventilation tower. The main role for the clock tower, or 'Big Ben', which easily dwarfed the twin towers of Westminster Abbey nearby, was to be London's 'premier time distributer', its glass face lit up until midnight. Supporters of Barry's architectural 'mechanics', such as the radical MP, Joseph Hume, envisaged the new parliament as a 'machine', a utilitarian engine for doing the people's work.

Ultimately, Gillin is better at conveying Barry's aspirations, rather than his achievements. Yorkshire stone crumbled in the climes of London. Reid was sacked, Airy replaced, and, at first, the deafening chimes of Big Ben proved unpopular. But the 'palace of science' tag stuck. Electric lighting was trialled in the House of Commons by the Edison Company in 1883, ahead of the rest of the nation. Telegraphy (1852) and telephony (1880) were also fast-tracked. ${ }^{20}$ And when Barry's edifice was partially destroyed by the blitz bombings of 1941, more experimentation followed, including the recording of debates by the $\mathrm{BBC}$ in the temporary chamber of the Commons, and the first use in the UK of reinforced concrete in the new chamber, completed in 1950, its innovative suspended design enabling many more offices and committee rooms to be added. ${ }^{21}$ The spatial turn in the history of parliament is thus revealing a

\footnotetext{
${ }^{18}$ Sean Sawyer, 'Delusions of national grandeur: reflections on the intersection of architecture and history at the Palace of Westminster, 1789-1834', Transactions of the Royal Historical Society, 6th ser., 13 (2003), pp. 237-50; M. H. Port, The Palace of Westminster: surveyed on the eve of the conflagration, 1834 (London, 2011).

${ }^{19}$ Ryan A. Vieira, Time and politics: parliament and the culture of modernity in nineteenth-century Britain and the British world (Oxford, 2015); Henrik Schoenefeldt, 'The historic ventilation system of the House of Commons, 1840-1852: re-visiting David Boswell Reid's environmental legacy', Antiquaries Journal, 98 (2018), pp. 245-95; Rebekah Moore, 'Old corruption to reformed parliament: St Stephen's, temporary accommodation and the new House of Commons', in J. P. D. Cooper, ed., St Stephen's Chapel and the Palace of Westminster (London and New Haven, CT, forthcoming).

${ }^{20}$ House of Commons Debates (HC Debs), 278 (17 Apr. 1883), cols. 426-7 (electric lighting); Moore, 'Old corruption to reformed parliament' (telegraphy); Times, 27 May 1880, p. 8 (telephony).

${ }^{21}$ See Miles Taylor, 'St Stephen's in war and peace: civil defence and the location of parliament, 1938-1951', in Cooper and Gaunt, eds., Space and sound in the British parliament, pp. 135-48; Gavin Stamp, "We shape our buildings and afterwards our buildings shape us": Sir Giles Gilbert Scott
} 
more dynamic Palace of Westminster. Behind the majestic exterior, new technology has continually developed to speed up business and connect with the outside world. Future research might tell us more. How, for example, the internal layout of the Palace has affected the behaviour and emotions of MPs and peers over time; and how parliament connects with its immediate environs in Westminster, Whitehall, and beyond.

\section{II}

The gothic setting of the Palace of Westminster not only disguises the modern engineering beneath, it also adds to the insular narrative that celebrates the British system as one of the oldest, the 'mother of parliaments' as the MP John Bright claimed in $1865 .{ }^{22}$ In fact, the expansion of British parliamentary democracy in the Victorian era coincided with similar developments across much of the world. Important insights can be gleaned from a more global approach to the history of parliamentary representation, such as that developed recently in the special comparative issues of the flagship journal, Parliaments, Estates and Representation. From the liberal movements in the Hispanic world in the early part of the nineteenth century, through the creation of new national assemblies in western, southern, and central Europe during the era of the 1848 revolutions, onto the new legislatures of the American states and the Canadian provinces, and in Britain's settlement colonies too, parliaments became the norm. As Remieg Aerts and Joop van den Berg argue in their introduction to a wide-ranging collection of essays, the idea of parliament was transnational..$^{23}$ By the end of the nineteenth century, most of continental Europe had modified or rejected monarchical rule in favour of some form of representative government. The British parliament was one model, but the French and German versions were also admired. Many of these parliaments looked similar. They were neo-classical buildings with rotunda chambers, in which the seats were arranged in a semi-circle, with speeches being made from a central podium. In most cases, these new legislatures were not the product of popular revolution. Their democratic credentials arose from the fact that the third estate claimed its share in national government alongside the crown, the nobility, and the clergy. Sovereignty was contested, the people on the barricades may have been the means, but the claims of parliament were the end. ${ }^{24}$ Looked at this wider context, the British case is closer to the European model than is often assumed.

and the rebuilding of the House of Commons', in Riding and Riding, eds., Houses of Parliament, pp. 149-60.

${ }^{22}$ Times, 19 Jan. 1865 , p. 9. Bright was actually drawing attention to the irony of working men in the colonies having the vote, while many in Britain did not.

${ }^{23}$ For a recent work along similar lines, see Roger D. Congleton, Perfecting parliament: constitutional reform, liberalism, and the rise of western democracy (Cambridge, 2010); Pasi Ihalainen et al., eds., Parliament and parliamentarism: a comparative history of a European concept (New York, NY, and Oxford, 2016).

${ }^{24}$ For recent surveys of this period, see the two collections edited by Joanna Innes and Mark Philp: Re-imagining democracy in the age of revolutions: America, France, Britain, Ireland 1750-1850 
The ideal of parliament identifies several distinguishing features of the transnational parliamentary phenomenon of the nineteenth century. Publicity of proceedings was cardinal. Jens Späth points to the Cortes of Cádiz (1810) as well as the short-lived Sicilian parliament at Naples (1812) as leading the way in publishing a daily record of their debates. These parliaments also broke with the confessional states of the ancien régime, recognizing the right to representation for all religions. Belgium's secular constitution of 1831 was a beacon of civil liberty in this respect. By the 1860s, most parliaments ended other disabilities, particularly of Jews. Above all, these were liberal parliaments, limiting the exercise of royal prerogative on the one hand, but curbing the excesses of democracy on the other. In his chapter on the Hungarian parliament in 1867, András Cieger describes how the lower house limited the power of the 'king in parliament'. Elsewhere, the challenge to parliamentary authority came from below: from the people and those deputies who spoke in its name. Andreas Schulz's contribution on the German National Assembly of 1848 emphasizes how it was based on primary and secondary elections, to mitigate against the consequences of an 'uneducated' electorate. He also describes the rules drawn up inside the parliament to limit the length of speeches, so as to curb long-winded demagogues. Few of these European parliaments rushed into voting by ballot, only introducing the measure as an accompaniment to adult male suffrage, hoping to protect inexperienced voters from intimidation. ${ }^{25}$

In Parliaments in time, Michael Koß adds another dimension to our understanding of this wave of new institutions, by looking at the body of rules that managed their time and business. In his comparative study of Britain, France, Germany, and Sweden, based on ninety different procedural changes across the four systems, he distinguishes between 'talking' and 'working' legislatures, a typology that has also been developed by Kari Palonen. ${ }^{26}$ In the former, parliamentary procedures maximized time allowed for debate, but left to the executive overall control of the timetable. In the latter, legislation took priority, with the programme organized by subject. Insofar as these rules were agreed from within rather than imposed from above, they contributed towards 'legislative democracy'. Broadly speaking, talking or deliberative parliaments developed in Britain and France, whilst more bureaucratic systems emerged in Germany and Sweden.

(Oxford, 2013), and Re-imagining democracy in the Mediterranean, 1780-1860 (Oxford, 2018). Pierre Rosanvallon's Le sacre du citoyen: histoire du suffrage universal en France (Paris, 1992) is a seminal critique of 'democratization' in France.

${ }^{25}$ Malcolm Crook and Tom Crook, 'Reforming voting practices in a global age: the making and remaking of the modern secret ballot in Britain, France and the United States, c. 1600-c. 1950', Past \& Present, 212 (2011), pp. 199-237; Jan Teorell et al., eds., The causes and consequences of secret ballot reform, special issue, Comparative Political Studies, 50 (2017).

${ }^{26}$ Kari Palonen, 'Political theories of parliamentarianism', in Ihalainen et al., eds., Parliament and parliamentarism, pp. 219-27; idem, 'A comparison between three ideal types of parliamentary politics: representation, legislation and deliberation', Parliaments, Estates and Representation, 38 (2018), pp. 6-20. 
Both Koß and the contributors to The ideal of parliament bring out the resilience of parliamentarianism through the twentieth century despite war and authoritarianism. The interwar years were its darkest days. By 1939, the number of parliaments in Europe had halved, legislative overload and the extension of democracy weakening their efficiency. ${ }^{27}$ Thomas Raithel offers Weimar Germany as the classic case. Increasing amounts of legislative authority were devolved to the central state, paving the way for the Führerprinzip of the Third Reich. Similarly, in the parliament of the new kingdom of Hungary, Kálmán Pócza describes a reaction against open debate, a clamour for specialist committees and yearning for the head of state (i.e. the king) to use veto powers. The nationality question added to the instability of the period. For example, Stephanie Zloch shows how one third of the new Polish parliament after 1918 were national minorities, in a tense competition with older representatives who had cut their teeth in the imperial parliaments of Prussia, Germany, Austria, and Russia. The ideal of parliament ends on a happier note. The final section of the book describes the rejuvenation of parliament after the end of the Second World War. In Austria, Germany, and Italy, Marie-Luise Recker documents how new constitutions minimized the power of the president, and restored the authority of the legislature, returning to nineteenth-century precedents. Even in communist states, parliaments could flex their muscle, despite one-party control. Adéla Gjuricǒvá points out how the Czech National Assembly became the centre of Alexander Dubček's challenge to the government in 1968, and how later in 1989-90 it stood up to Vaclav Havel's Civic Forum, ensuring that the velvet revolution had parliamentary endorsement. The editors of The ideal of parliament do not press the point brought out by other scholars, namely that the modern European parliament, which began life as the European Parliamentary Assembly in Luxembourg in 1958 , is an unworthy successor to this long tradition of legislative democracy. ${ }^{28}$

Placed within this spectrum of modern European parliaments, Britain sits somewhere in the middle. Westminster did of course look different. Barry eschewed the rotunda parliament, although many of the other schemes placed before parliament before and after the fire of 1834 did favour semi-circular design. ${ }^{29}$ But in most other respects, the parallels across the nineteenth century are striking. Britain's reputation as a constitutional monarchy, in which the crown was not supposed to interfere in parliament, sometimes looks closer to the European experience. There was a near miss in 1831, when William IV held out against the reform bill, a stand-off between Lords and Commons in 1910 with Edward VII primed to intervene, and rumours of a palace

\footnotetext{
${ }^{27}$ On this theme, see also Gerald Kohl, ed., Glory and misery of the parliamentary concept, 1918-1938, special issue, Parliaments, Estates and Representation, 40 (2020).

${ }^{28}$ For criticism of the European parliament's democratic deficit, see David M. Farrell and Roger Scully, Representing Europe's citizens?: electoral institutions and the failure of parliamentary representation (Oxford, 2007); Richard Bellamy, A republican Europe of states: cosmopolitanism, intergovernmentalism and democracy in the EU (Cambridge, 2019).

${ }^{29}$ Sawyer, 'Delusions of national grandeur'; Paul Seaward, 'Do our buildings shape us? On oblongs, hemicycles and the style of British politics', in Cooper, ed., St Stephen's Chapel and the Palace of Westminster.
} 
revolution' to oust the Labour government in $1931 .^{30}$ Britain followed European precedents in giving greater publicity to parliamentary proceedings, although until 1905 there was no official record of the debates, with newspaper reporters relied on for copy. Statutes were publicly promulgated from $1835 .{ }^{31}$ Parliamentary procedure was overhauled around the same time, with the government asserting its control over the legislative calendar. ${ }^{32}$ Like most of their European counterparts, the British limited changes to the electoral system, taking the best part of a century to bring in full adult suffrage (1928), and, in the face of much opposition, only bringing in the secret ballot in 1872 as a preventive move, in order to purge corruption in elections in Ireland, and in local government in England. ${ }^{33}$ Britain was off the pace in terms of religious disabilities. Catholics and dissenters were not emancipated until the late 1820s, Jews in 1858 (long after some of Britain's own colonies). Alone amongst modern parliaments, Westminster insisted on a religious oath from new MPs until $1888 .^{34}$ As on the continent, parliamentary verbosity was outlawed, with new rules introduced in 1841 limiting speeches on public petitions. At the same time, the Commons and the Lords honed a national reputation for 'government by speaking', based on the deliberative prowess of parliament. ${ }^{35}$

In one respect, British parliamentarianism was quite unlike the European experience: its system of representation. Whereas most European parliaments were chosen by electoral colleges in single-member constituencies that corresponded to the main administrative divisions of the state, Britain, until well into the twentieth century, preserved its old medieval organization,

${ }^{30}$ Richard W. Davis, A political history of the House of Lords, 1811-1846: from the regency to corn law repeal (Stanford, CA, 2008), ch. 11; David Powell, The Edwardian crisis: Britain, 1901-1914 (Basingstoke, 1996), ch. 2; Stuart Ball, 'The Conservative party and the formation of the national government: August 1931', Historical Journal, 29 (1986), pp. 159-82.

${ }^{31}$ John Prest, 'The promulgation of the statutes', in David M. Dean and Clyve Jones, eds., Parliament and locality, 1660-1939, special issue, Parliamentary History, 17 (1998), pp. 106-12; Kathryn Rix, "Whatever passed in parliament ought to be communicated to the public": reporting the proceedings of the reformed Commons, 1833-1850', ibid., 33 (2014), pp. 453-74; John Vice and Stephen Farrell, The history of Hansard (London, 2017), ch. 7.

${ }^{32}$ Valerie Cromwell, 'The losing of the initiative by the House of Commons, 1780-1914', Transactions of the Royal Historical Society, 5th ser., 18 (1968), pp. 1-23; Gary W. Cox, The efficient secret: the cabinet and the development of political parties in Victorian England (Cambridge, 1987).

${ }^{33}$ Martin Pugh, The evolution of the British electoral system, 1832-1987 (London, 1988), remains the best overview of franchise reform. For the ballot, see Bruce Kinzer, The ballot question in nineteenthcentury English politics (New York, NY, 1982); Malcolm Crook and Tom Crook, 'The advent of the secret ballot in Britain and France, 1789-1914: from public assembly to private compartment', History, 92 (2007), pp. 449-71.

${ }^{34}$ For Catholic emancipation in Britain (especially within a European context), see K. Theodore Hoppen, 'Riding a tiger: Daniel O'Connell, reform, and popular politics in Ireland, 1800-1847', in T. C. W. Blanning and Peter Wende, eds., Reform in Great Britain and Germany, 1750-1850 (Oxford, 1999), pp. 121-43. For the Christian oath, see Dennis Grube, 'Religion, power and parliament: Rothschild and Bradlaugh revisited', History, 92 (2007), pp. 21-38.

${ }^{35}$ Christopher Reid, Imprison'd wranglers: the rhetorical culture of the House of Commons 1760-1800 (Oxford, 2012); Joseph Meisel, Public speech and the culture of public life in the age of Gladstone (New York, NY, 2001). For the new rules on speeches on petitions, see Thomas Erskine May, A treatise upon the law, privileges, proceedings and usage of parliament (London, 1844), p. 307. 
differentiating between boroughs (burghs in Scotland) and counties. Double-member seats were retained, as were the conventions of plural voting. The peculiarities of Britain's territorial system of representation have been largely overlooked by modern historians, who focus on the expansion of the franchise, rather than the distribution of constituencies. The classical political theory of representation also assumes that modern liberalism put paid to older ways. ${ }^{36}$ Yet suffrage reform was always only one part of the legislation comprising 'representation of the people'. Until 1928, it was an axiom of British politics that although not everyone had the vote, everyone was represented in some way. Moreover, many people had more than one vote, a convention that survived until 1948. It is too easy to write this off as failing the test of democracy, without at least trying to understand how it was not only defended in theory, but also worked in practice.

\section{III}

Gregory Conti's monograph is the first full treatment of debates around mixed suffrages and virtual representation in the nineteenth century. Seminal studies of popular electoral culture have shown how political participation in Hanoverian and Victorian Britain went well beyond those who possessed the vote. ${ }^{37}$ Historians of the 'unreformed' parliament (that is, before 1832) have also revealed how MPs served a range of interest groups and lobbies beyond their own constituency through indirect connections of residence and family, as well as via their financial and professional networks. ${ }^{38}$ However, the theories that lay behind these practices have eluded study. In the first half of his book, Conti recovers a substantial tranche of Victorian political commentary devoted to explaining how the very lack of uniformity in the electoral system guaranteed its effective working. MPs from large working-class electorates such as Westminster ensured that the interests of poorer Britons elsewhere were looked after. Conversely, the propertied elites enjoyed more than one vote, so that they would not be dominated by the more numerous working classes. Virtual representation justified other anomalies. For example, enfranchising the relatively small river port of Sunderland meant that the shipping

\footnotetext{
${ }^{36}$ John Hostettler and Brian Block, Voting in Britain: a history of the parliamentary franchise (Chichester, 2001); Ian Machin, The rise of democracy in Britain, 1830-1918 (Basingstoke, 2001); Hugh Cunningham, The challenge of democracy: Britain, 1832-1918 (Harlow, 2001); Paul Foot, The vote: how it was won and how it was undermined (London, 2005); Nicole B. Springer, ed., A history of voting rights for parliamentary elections in the United Kingdom (New York, NY, 2014); Pitkin, Concept of representation, p. 191; Birch, Representation, pp. 51-3.

${ }^{37}$ Frank O'Gorman, 'Campaign rituals and ceremonies: the social meaning of elections in England, 1780-1860', Past \& Present, 135 (1992) pp. 79-115; James Vernon, Politics and the people: a study in English political culture, c. 1815-1867 (Cambridge, 1993); Jon Lawrence, Electing our masters: the hustings in British politics from Hogarth to Blair (Oxford, 2009), ch. 1.

${ }^{38}$ Paul Langford, 'Property and virtual representation in eighteenth-century England', Historical Journal, 31 (1988), pp. 83-115; Yasushi Aoki, 'Members of parliament and their connections to constituencies in the eighteenth century: a study in quantitative political history', Parliaments, Estates and Representation, 18 (1998), pp. 71-82; Julian Hoppit, 'Petitions, economic legislation and interest groups in Britain, 1660-1800', Parliamentary History, 37 (2018), pp. 52-71.
} 
industry in other parts of the country was represented. Diversity in the electorate produced a more deliberative House of Commons as well, as MPs were not tied to the demands of one class of voter. Conti describes how a host of major figures - Walter Bagehot, W. R. Greg, the 3rd Earl Grey, Sir James Mackintosh, and Lord John Russell - supported by a cast of lesser-known writers - Henry Creasy, James Lorimer, Henry Pochin, and Augustus Stapleton defended virtual representation from the advocates of more direct democracy, such as John Stuart Mill.

Conti also begins to unpack the idea of 'interests', that is to say, the principle that the Commons represented corporate groups or sectors such as agriculture, railways, manufacturing, and bankers, rather than individuals or classes. For Victorians, the distribution of parliamentary constituencies and seats was proportionate to the importance of a particular 'interest'. For example, until 1885, the City of London, Britain's financial hub, returned four MPs. Although its electorate was of middling size, its MPs were supposed to serve the commercial needs of the rest of the country. How all this worked in practice remains unexplored. In the 1970s and 1980s, quantitative studies of parliamentary behaviour assembled a vast amount of data on MPs and their personal and constituency backgrounds, in order to measure party alignment around the time of the crises over the corn laws and home rule for Ireland. ${ }^{39}$ All this statistical information is worth revisiting for a better understanding of how parliament represented 'interests'. Instead of focusing on division lists (or 'roll calls'), researchers might instead plot the links between MPs and legislation (and its accompaniments in the form of public petitions and service on committees). ${ }^{40}$

Highly convincing on the persistence of virtual representation into the reform era of the 1860s, Conti is less persuasive when he turns to explain its nemesis: the idea of proportional representation. Other scholars, notably Floyd Parsons, have chronicled the popularity of Thomas Hare's scheme of proportional or 'personal' representation (PR), emphasizing how it developed as a critique of virtual representation. Hare was worried that minority views were

\footnotetext{
${ }^{39}$ William O. Aydelotte, 'Constituency influence on the British House of Commons, 1841-7', in Aydelotte, ed., The history of parliamentary behaviour (Princeton, NJ, 1977), pp. 225-46; Valerie Cromwell, 'Mapping the political world of 1861: a multi-dimensional analysis of House of Commons division lists', Legislative Studies Quarterly, 7 (1982), pp. 281-97. See also Marc Baer, 'Members of the House of Commons, London, 1852-1867' (1977), UK Data Service, SN. 218, http://doi.org/10.5255/UKDA-SN-218-1; William C. Lubenow, Parliamentary politics and the home rule crisis: the British House of Commons in 1886 (Oxford, 1988). For later applications of some of this data, see Cox, Efficient secret; Iain McLean, 'Rational choice and the Victorian voter', Political Studies, 40 (1992), pp. 496-515; and for a study which extends Aydelotte's data back into the 1830s, see Cheryl Schonhardt-Bailey, From the corn laws to free trade: interests, ideas, and institutions in historical perspective (Cambridge, MA, 2006).

${ }^{40}$ So far, it looks as though new quantitative studies will use such data to continue the older focus on the 'modernization' of the electorate, rather than analyse the changing system of representation: Thomas Ertman, 'The Great Reform Act of 1832 and British democratization', Comparative Political Studies, 43 (2010), pp. 1000-22; Toke S. Aidt and Raphaël Franck, 'What motivates an oligarchic elite to democratize? Evidence from the roll call vote on the Great Reform Act of 1832', Journal of Economic History, 79 (2019), pp. 773-825.
} 
left unrepresented by simple numerical majorities, a diagnosis that influenced John Stuart Mill. ${ }^{41}$ However, Conti surely overstates the significance of PR as a game-changer. Hare's mathematical formulas went down badly. As Conti himself concedes, Hare's Treatise on the election of representatives, parliamentary and municipal (1859) was 'far from limpid', leaving readers with the impression that PR was 'confused and overcomplicated'. Similarly, Mill's support for PR was seen as special pleading for an educated elite. PR fared better overseas in some of the smaller electorates of the British empire-for example, Queensland (1892), Tasmania (1909), and Malta (1921) - than it did at home. In the longer term, the campaign for PR in the UK only gained traction when the governing party of the day was dependent on a third party, for example, Ramsay MacDonald in 1929, James Callaghan in 1977, and David Cameron in 2010.

Moreover, the system of virtual representation proved more pervasive and enduring than Conti allows. Direct representation in the form of singlemember constituencies did not arrive overnight in the mid-1880s as is sometimes assumed. ${ }^{42}$ The Second Reform Act of 1867 had extended the principle of multi-member seats, adding a third member to the representation of Birmingham, Leeds, Liverpool, and Manchester. After 1885, alongside an extensive reorganization of county constituencies, twenty-four parliamentary boroughs returning two MPs remained in England and Ireland, only phased out in 1918. A mixed and messy franchise lasted too. Whilst many old corrupt boroughs were disfranchised by the First Reform Act of 1832, old suffrages - the infamous freeman, 'scot and lot', and 'pot-walloper' franchises - continued during the lifetime of those registered under these qualifications at the time. Well into the 1860s, freeman voters in particular formed a sizeable part of the local electorate in medium-sized towns such as Chester, Coventry, and Preston. ${ }^{43}$ Other features of virtual representation survived. Petitioning of parliament, which allowed the voices of non-electors to be heard, continued unabated into the early twentieth century, as much a part of the ammunition of the

\footnotetext{
${ }^{41}$ F. D. Parsons, Thomas Hare and political representation in Victorian Britain (Basingstoke, 2009); Jenifer Hart, Proportional representation: critics of the British electoral system, 1820-1945 (Oxford, 1992); Ted Bromund, 'Uniting the whole people: proportional representation in Great Britain, 1884-1885, reconsidered', Historical Research, 74 (2001), pp. 77-94.

${ }^{42}$ For work which emphasizes 1885 and 1918 as turning points, see Mary Chadwick, 'The role of redistribution in the making of the Third Reform Act', Historical Journal, 19 (1976), pp. 665-83; Peter Catterall, 'The politics of electoral reform since 1885', in Catterall et al., eds., Reforming the constitution: debates in twentieth-century Britain (London, 2000), pp. 129-57; Matthew Roberts, 'Resisting "arithmocracy": parliament, community, and the Third Reform Act', Journal of British Studies, 50 (2011), pp. 381-409; Stuart Ball, 'The Reform Act of 1918 - the advent of democracy', in Ball, ed., The advent of democracy: the impact of the 1918 Reform Act on British politics, special issue, Parliamentary History, 37 (2018), pp. 1-22.

${ }^{43}$ Miles Taylor, 'Interests, parties and the state: the urban electorate in England, c. 1820-1872', in Jon Lawrence and Miles Taylor, eds., Party, state and society: electoral behaviour in Britain since 1820 (Aldershot, 1997), pp. 50-78. For specific case-studies, see Peter Searby, 'Chartists and freemen in Coventry, 1838-1860', Social History, 6 (1977), pp. 761-84; P. J. Shinner, 'Continuity in the age of reform: freemen and the persistence of the old order in nineteenth-century Grimsby', Midland History, 37 (2012), pp. 163-86.
} 
suffragette movement as it had been for temperance reformers and sabbatarians across the nineteenth century. ${ }^{44}$ Virtual representation also enjoyed a new lease of life in the arguments of the anti-suffragists, insistent that fathers and husbands were proxy voters, indirectly representing the interests of their daughters and wives. ${ }^{45}$

Similarly, plural voting did not die a death in the later nineteenth century. The principle that someone was entitled to a vote for each property that they owned or occupied remained sacrosanct until after the First World War. Even then, 'one person, one vote' did not extend to university graduates. Five more university constituencies were added to the representation in 1918 (Combined English universities, Combined Scottish universities, the National University of Ireland, Queen's University Belfast, and the University of Wales). ${ }^{46}$ And in the one entirely new parliamentary system created within the UK between the thirteenth and the twentieth centuries - the parliament of Northern Ireland (1920-72) - plural voting was brought back in, insofar as business premises as well as household residences provided an electoral qualification until $1968 .^{47}$ Long after 1918, the British electoral system remained variegated. Only in 1948 was there a bonfire of all the election laws that dated back to the era of Simon de Montfort and Edward I. The Representation of the People Act of that year removed hundreds of old election statutes, putting in their place the main features of the system that exists until this day. County and urban representation converged into single member constituencies, and the university seats together with the 'business vote' of the City of London were abolished. ${ }^{48}$ Seen in this way, modern British democracy is a relatively recent invention, the product of war and the expansion of central government in the twentieth century, rather than an organic growth of people power from the late eighteenth century. Instead of censuring the Victorians and Edwardians for clinging to the old ways of parliamentary representation, scholars need to learn more about how it operated successfully for so long.

\section{IV}

Parliaments could be neither 'talking' nor 'working' legislatures, to coin Michael Koß's useful distinction, without an agreed set of rules. In most parliamentary systems, a Speaker holds the ring, guided by conventions that have grown up over the years, and been codified to a varying extent. Neither the office nor the rules have attracted much attention. In Britain,

\footnotetext{
${ }^{44}$ Richard Huzzey and Henry Miller, 'Petitions, parliament and political culture: petitioning the House of Commons, 1780-1918', Past \& Present, 248 (2020), pp. 123-64.

${ }^{45}$ Brian Harrison, Separate spheres: the opposition to women's suffrage in Britain (London, 1978).

${ }^{46}$ Michael Rohan, 'University representation, 1918-1938', Administration, 29 (1982) pp. 260-89; Joseph Meisel, 'A magnificent fungus on the political tree: the growth of university representation in the United Kingdom, 1832-1950', History of Universities, 23 (2008), pp. 109-86.

${ }^{47}$ Sydney Elliott, 'Voting systems and political parties in Northern Ireland', in Brigid Hadfield, ed., Northern Ireland: politics and the constitution (Buckingham, 1992), pp. 76-93.

${ }^{48}$ The 1948 Reform Act awaits a proper history. For a contemporary account, see J. F. S. Ross, Parliamentary representation (2nd edn, London, 1948), a much expanded version of the 1943 original.
} 
the 'bible' of procedure is Thomas Erskine May's Treatise upon the law, privileges and proceedings of parliament, first published in 1844 and now in its 25th edition. A weighty and dry tome, the Treatise enjoyed the spotlight during the Brexit debates of 2019 when the Speaker John Bercow cited May in ruling that the Commons could not vote twice on a similar amendment. ${ }^{49}$ Bercow also ensured that the Treatise became better known (if not actually read) by supporting its digitization. All this renewed interest coincided with the bicentenary of May's birth, commemorated in a wide-ranging volume, Essays on the history of parliamentary procedure.

The biographical portions of this collection describe how May dedicated his career to understanding and reforming the work of the Commons, particularly the machinery of legislation. May's was not the first attempt to synthesize and improve parliamentary procedure. In his chapter, Paul Seaward chronicles a long tradition of guides stretching back to the early eighteenth century, the most influential of which was that of John Hatsell, clerk of the Commons from 1768 to $1820 .^{50}$ Hatsell favoured following precedent. Clerks, and aspiring MPs, needed to be familiar with what the Commons had done in the past, and that meant mastering the daily record of the Commons, the Journal. May joined the Clerks' Office in 1831, straight from school, serving an apprenticeship in the library of the Commons by re-indexing the Journal. Whilst May was schooled in the old ways, he was also a child of the new age of information. William McKay, who recounts May's life, does not mention the enormous amount of data about the workings of the Commons amassed by May. Lists of bills, committee attendance as well as laborious analyses of the frequency and length of MPs' speeches and other aspects of the Commons timetable fill his own private notebooks from the period. ${ }^{51}$ He campaigned for reform of the way the Commons worked, calling for a streamlining of Commons business. May favoured grouping bills according to topic, and also delegating the routine parts of legislation to standing committees.

As a manual of rules and etiquette, May's book quickly proved indispensable, cited as the 'standard authority' within a decade. ${ }^{52}$ The rising authority of the Treatise was complemented by the ascent of the stature of the Speaker, particularly during the offices of Charles Shaw-Lefevre (1839-57) and Henry Brand (1872-84). In the new Palace, Barry set aside as much space for the Speaker's accommodation as he did for the Commons, yet the ceremonial and procedural functions of the office in the modern period await fuller analysis. ${ }^{53}$ May's Treatise secured a wide audience overseas. A jointly written chapter in the volume describes May's influence in the colonies, notably New Zealand, Australia, and Canada. May became a one-man advisory

\footnotetext{
${ }^{49}$ www.theguardian.com/politics/2019/mar/18/what-has-john-bercow-done-now.

${ }^{50}$ For Hatsell, see Peter J. Aschenbrenner and Colin Lee, eds., The papers of John Hatsell, clerk to the House of Commons (Camden Fifth Series, vol. 59, Cambridge, 2020).

${ }^{51}$ T. E. May papers, Parliamentary Archives, Houses of Parliament, ERM/18.

${ }^{52}$ HC Debs, 133 (1 June 1854), col. 1166 (Sir John Pakington).

${ }^{53}$ So far, there are only two significant studies: Philip Laundy, The office of Speaker (London, 1964); Paul Seaward, ed., Speakers and the speakership: presiding officers and the management of business from the middle ages to the 21st century, special issue, Parliamentary History, 29 (2010).
} 
service, replying to queries from speakers and clerks in the legislatures of the new world. Beyond the anglosphere, the Treatise also had an impact, being translated into German in 1860, with later Hungarian (1866) and Italian editions (1888) too. In the end, everyone else seems to have benefited from the success of the Treatise except May himself. His progress up the slippery pole of patronage in the clerks' office was slow. He only became clerk of the Commons in 1870, after almost forty years' service.

The ninth edition of the Treatise in 1883 was the last one published in May's lifetime. Thereafter, updating the rule-book became a collective endeavour. Much of the second half of this volume covers the history of parliamentary procedure since the late nineteenth century. We learn from Simon Patrick about the reform of standing orders in the 1850s and 1900s, neglected by historians. As Koß shows in his book, this was a key instrument in regulating the business of the legislature, and requires much fuller historical analysis. Of the current standing orders in the Commons, 40 per cent originate from before $1914 .^{54}$ The procedural reforms of the 1940s and 1960s are given due attention, particularly those forced through by Richard Crossman. ${ }^{55}$ And the way in which the 'centre of gravity' of the Commons has shifted from the chamber to the committee room is highlighted by several of the contributors, including the editor, Paul Evans, as select committees have taken over many of the deliberative and interrogative tasks once performed within the Commons itself. ${ }^{56}$ With one or two exceptions, the contributors to this belated festschrift for May are mainly clerks and former clerks of the House of Commons. Some of them place too much emphasis on the 'working' of parliament, and not enough on the 'talking' element, almost as though MPs are a tiresome obstacle in the way of 100 or so clerks wishing to go about their business. They would do well to recall May's own wariness of bureaucracy. 'Ours is not a council of sages for framing laws, and planning amendments of the constitution; but a free and vigorous parliament, which watches over the destinies of an empire', he concluded in his Constitutional history of England. ${ }^{57}$ However, the volume unequivocally asserts the importance of procedure in understanding how parliament has changed over time. Indeed, the essays close out in a provocative fashion, with David Howarth making the case for parliament's own rules,

\footnotetext{
${ }^{54}$ Calculated from Standing orders HC 314 (House of Commons, 2019), pp. xiii-xxiii. The one historical account is O. C. Williams, The historical development of private bill procedure and standing orders in the House of Commons (2 vols., London, 1948-9).

${ }^{55}$ For a fuller account of Crossman's work, see Peter Dorey and Victoria Honeyman, 'Ahead of his time: Richard Crossman and House of Commons reform in the 1960s', British Politics, 5 (2010), pp. 149-78. A comparable study for Herbert Morrison's reforms of the 1940s is needed. For a contemporary verdict, see Gilbert Campion, 'Parliamentary procedure, old and new', in Campion, ed., Parliament: a survey (London, 1952), pp. 141-57.

${ }^{56}$ For amplification of this theme, see Paul Evans et al., eds., 40 years of Departmental Select Committees in the House of Commons, special issue, Parliamentary Affairs, 72 (2019). For a contrary view, see Philip Aylett, 'Did 1979 make much difference? An alternative view of Select Committee reform in the 1970s and 1980s', Parliamentary History, 39 (2020), pp. 311-30.

${ }^{57}$ Thomas Erskine May, The constitutional history of England since the accession of George the Third, 1760-1860 (2 vols., London, 1861-3), II, p. 622.
} 
the lex parliamenatria, having the same status as statute law. The question of who rules parliament is vexed, and, as we shall see, has been left unresolved by the Brexit crisis.

Unlike the Bible, May's Treatise left out women almost entirely. They only merited mention in a paragraph describing the infamous 'grille', that is the Ladies' Gallery in the Commons, from which they were permitted to view proceedings on the benches below through a barred grate. ${ }^{58}$ All that changed by the time of the thirteenth edition of the Treatise, published in 1924. With the extension of the suffrage in 1918 to all married women over the age of thirty, and the accompanying Parliament (Qualification of Women) Act, women joined the Commons for the first time. A new paragraph was added to the Treatise. ${ }^{59}$ More significantly, a new chapter opened in the history of parliamentary representation.

Currently a Labour MP herself, Rachel Reeves has written a compendious account of the first century of women MPs. One of several books published to mark the centenary of the 1918 Representation of the People Act, hers is an accessible and well-informed chronicle of the slow growth of what she calls the 'sisterhood' at Westminster. ${ }^{60}$ Other historians, notably Brian Harrison and Pat Thane, have pointed to the glacial pace at which the Commons opened up to women. Despite a long tradition of women's political activism across the party spectrum in the UK in the nineteenth and early twentieth centuries, alongside almost a half-century of elected membership of local authorities such as education and poor law boards, it took women many decades to crack open parliament. In 1945, there were still only fourteen women in the Commons. ${ }^{61}$ In fact, as Reeves shows, more than two-thirds of the total 491 women MPs since 1918 have been elected during and since new Labour's landslide of 1997. Not that this is another British exception. Most white Anglo-Saxon democracies struggled to make headway on equal

\footnotetext{
${ }^{58}$ Clare Eustance, 'Protests from behind the grille: gender and the transformation of parliament, 1867-1918', Parliamentary History, 16 (1997), pp. 107-26; Sarah Richardson, 'Parliament as viewed through a woman's eyes: gender and space in the 19th-century Commons', in Cooper and Gaunt, eds., Space and sound in the British parliament, pp. 119-34.

${ }^{59}$ May, Treatise (13th edn, London, 1924), ch. 11; Mari Takayanagi, 'Sacred year or broken reed? The Sex Disqualification (Removal) Act 1919', Women's History Review, 29 (2020), pp. 563-82.

${ }^{60}$ Other centenary volumes include Ball, ed., The advent of democracy; Dawn Langan Teele, Forging the franchise: the political origins of the women's vote (Princeton, NJ, 2018); Jane Robinson, Hearts and minds: suffragists, suffragettes and how women won the vote (London, 2018); Nan Sloane, The women in the room: Labour's forgotten history (London, 2018).

${ }^{61}$ Brian Harrison, 'Women in a men's house: the women M.P.s, 1919-1945', Historical Journal, 29 (1986), pp. 623-54; Pat Thane, 'Women and political participation in England, 1918-1970', in Pat Thane and Esther Breitenbach, eds., Women and citizenship in Britain and Ireland in the twentieth century: what difference did the vote make? (London, 2010), pp. 11-28; Jane Rendall, ed., Equal or different: women's politics 1800-1914 (Oxford, 1987); Patricia Hollis, Ladies elect: women in English local government, 1865-1914 (Oxford, 1987); Myriam Boussahba-Bravard, ed., Suffrage outside suffragism: women's vote in Britain, 1880-1914 (New York, NY, 2007).
} 
representation once they had conceded equal suffrage. Scandinavian countries proved quicker to alter the gender balance of their legislatures, as did many of the new parliaments forged out of the peace negotiations at the end of the First World War, for example Austria, the Czech Republic, Germany, Latvia, and Poland. ${ }^{62}$

Historians have described a combination of obstacles facing women as MPs in the UK. These include the persistence of the Victorian convention of 'separate spheres' whereby women were defined by their domestic role; the lack of positive discrimination in favour of women candidates; and the hostile masculine environment of the Commons itself, its atmosphere and working hours more like a men's club. ${ }^{63}$ To this list might be added the legacy of "virtual representation', emphasized by Conti, that is to say the convention that the Commons represented 'interests' not people, interests necessarily being defined in patriarchal terms. ${ }^{64}$ Moreover, if, as the Aerts and Koß volumes suggest, the British parliament was more of a 'speaking' than a 'working' legislature, then the oratorical brilliance and theatrical performativity prized by the Commons were exclusively male attributes, learned in the classical curriculum of the elite schools and the older universities, and in many cases polished by legal careers. ${ }^{65}$ 'Government by speaking', based on adversarial advocacy - the combative 'cut and thrust' of debate-compounded the challenges faced by new women entrants to the Commons.

Women at Westminster is peppered with anecdotes and stories that bear out the institutional bias against women that has long been a feature of parliament. Reeves shows how women MPs were more likely to be singled out by male parliamentarians and by the media for how they spoke and dressed, rather than for what they said or stood for. She brings out clearly the contradiction at the heart of the old Burkean ideal of representation, namely that women were expected to be in parliament on merit, not as a special or minority category, whilst at the same time once they were in the Commons they

\footnotetext{
${ }^{62}$ Maurice Duverger, The political role of women (Paris, 1955), pp. 75-98; Mercedes Mateo Diaz, Representing women? Female legislators in West European parliaments (Colchester, 2005), pp. 39-49.

${ }^{63}$ Martin Pugh, Women and the women's movement in Britain, 1914-1999 (Basingstoke, 2000); Julie Gottlieb and Richard Toye, eds., The aftermath of suffrage: women, gender and politics in Britain, 1918-1945 (Basingstoke, 2013).

${ }^{64}$ Feminist political theory has focused on this theme, notably Carole Pateman, The disorder of women: democracy, feminism and political theory (Stanford, CA, 1989); and Anne Phillips, Engendering democracy (Cambridge, 1991); and idem, The politics of presence: the political representation of gender, ethnicity and race (Oxford, 1995). As yet, there is a lack of empirical research on patriarchy in political rhetoric before 1918. But see Harrison, Separate spheres; Jane Rendall, 'John Stuart Mill, liberal politics and the movements for women's suffrage, 1865-1873', in Amanda Vickery, ed., Women, privilege and power: British politics, 1750 to the present (Stanford, CA, 2001), pp. 168-200; Ben Griffin, The politics of gender in Victorian Britain: masculinity, political culture and the struggle for women's rights (Cambridge, 2012), pp. 203-15, 298-300.

${ }^{65}$ For the eighteenth and nineteenth centuries, see Reid, Imprison'd wranglers; Meisel, Public speech. For the twentieth century, see Richard Toye, 'The House of Commons in the aftermath of suffrage', in Gottlieb and Toye, eds., The aftermath of suffrage, pp. 70-86; Josephine Hoegaerts, 'Speaking like intelligent men: vocal articulations of authority and identity in the House of Commons in the nineteenth century', Radical History Review, 121 (2015), pp. 123-44.
} 
were usually directed to 'women's' issues (health, childcare, and education) in their backbench and frontbench duties. No surprise then that the one peak of power they conquered was the Ministry of Education and its successor departments. Women have been secretaries of state for education for twenty-four of the last hundred years. ${ }^{66}$ Reeves's chronicle is also a positive account, emphasizing the extent to which it has been women MPs, often in cross-party co-operation, who have fundamentally changed British politics and society. The struggle for equal suffrage, equal guardianship after separation and divorce, the family allowance, equal pay, abortion on the British mainland (in the 1960s) and in Northern Ireland more recently, school nutrition, and many other measures, could not have been achieved without the pressure from within parliament from a long line of women MPs.

In Reeves's opinion, the turning point in the fortunes of women at Westminster came in 1997 with the decision by Tony Blair's Labour party to back all women short-lists. A decade or so later, David Cameron followed suit in a watered-down way with an 'A-list' of 100 eligible women candidates who were recommended for special consideration by constituency parties. It is not self-evident that these soft quotas made all the difference. Within a large political science literature, the jury is still out on both what better representation for women entails, and also on whether a 'critical mass' of women in the main parliamentary parties was required before quotas were introduced. ${ }^{67}$ Seen in this way, the Blair reforms may have been as much about the transformation of Labour's notoriously masculine mentality as they were about parliament itself changing its ways. ${ }^{68}$

Reeves understandably credits her own party with improving the lot of women at Westminster. Leading Labour ladies dominate her book, starting with Ellen Wilkinson, then moving onto Edith Summerskill, Barbara Castle, Jennie Lee, Shirley Williams, and Harriet Harman. On the Tory side, there seems less to say. Nancy Astor (the first woman to take a seat in the Commons) receives due attention. Later, Margaret Thatcher gets full coverage, although the tone is chillier here as Reeves documents the 'iron lady's' famous inability to work with other women. Nor is there much coverage of women from other parties, even though historically they have fielded a larger

\footnotetext{
${ }^{66}$ For the record up to 1974, see Robin Betts, 'Parliamentary women: women ministers of education, 1924-1974', in Joyce Goodman and Sylvia Harrop, eds., Women, educational policy-making and administration in England: authoritative women since 1800 (London, 2000), pp. 175-92.

${ }^{67}$ Linda Trimble et al., eds., Representing women in parliament: a comparative study (London, 2006); M. Trembley, ed., Women and legislative representation: electoral systems, political parties, and sex quotas (London, 2008); Maria Escobar-Lemmon and Michelle Taylor-Robinson, eds., Representation: the case of women (Oxford, 2014). On all-women shortlists, see Sarah Childs, New Labour's women MPs: women representing women (London, 2004).

${ }^{68}$ Pamela M. Graves, Labour women: women in British working class politics, 1918-1939 (Cambridge, 1994); Amy Black and Stephen Brooke, 'The Labour party, women, and the problem of gender, 1951-1966', Journal of British Studies, 36 (1997), pp. 419-62; June Hannam, 'Women and labour politics', in Matthew Worley, ed., The foundations of the British Labour party: identities, cultures and perspectives, 1890-1939 (Aldershot, 2009), pp. 171-92.
} 
proportion of female candidates. ${ }^{69}$ Eleanor Rathbone, perhaps the most effective independent MP of all time, is in the book, but nationalist MPs are largely excluded (nothing on the SNP's Ewings (Margaret and Winnie), or Margo MacDonald, and only en passant references to the independent Catholic socialist, Bernadette Devlin, and the Ulster Unionist party's Patricia McLaughlin). All of these women broke the mould in different ways. Likewise, women from the smaller UK mainland parties, such as Caroline Lucas of the Greens, are missed out altogether. Recent analysis of parliamentary debates across the twentieth century actually suggests that a more pro-active style of women's representation came before 1997 not after, when women were in a smaller minority. ${ }^{70}$ More analysis of women as legislators between 1945, when Brian Harrison's analysis ends, and the 1990s, when quantitative analysis started up, is required for a fuller picture.

\section{VI}

Reeves's rose-coloured rollcall of women in parliament is confined to the House of Commons. Over in the Lords, the story is slightly different. Although the proportion of women in the upper chamber currently lags behind the lower at 28 per cent, change came relatively quickly after the Life Peerages Act of 1958, which ended male dominance of the Lords. Within ten years, double the number of female peers had been created compared to the number of women MPs elected in the ten years after $1918 .^{71}$ The House of Lords may seem an unlikely pacesetter in the history of constitutional change. Traditionally, the Lords has been seen as the most sluggish part of parliament, still intact despite more than a century of attempts at reform. ${ }^{72}$

Philip Norton (Lord Norton of Louth) is both an academic political scientist and a member of the House of Lords (since 1998). He has always been drawn to the less fashionable parts of the British political system. From his early work on backbench MPs, to his more recent analyses of the cabinet and the courts,

${ }^{69}$ Christopher Jones, 'House of Commons trends: how many women candidates become MPs?' (30 Oct. 2020), citing data from British electoral facts, 1832-2006, comp. Colin Rallings and Michael Thrasher (London, 2017), https://commonslibrary.parliament.uk/house-of-commons-trends-howmany-women-candidates-become-mps/.

${ }^{70}$ Luke Blaxill and Kaspar Beelen, 'A feminized language of democracy? The representation of women at Westminster since 1945’, Twentieth Century British History, 27 (2016), pp. 412-49; Karine Rivière-De Franco, 'The parliamentary behaviour of women and men MPs: equal status, similar practices?', La revue LISA, 12 (2014), https://doi.org/10.4000/lisa.6877. For a more standard interpretation, see Paul Chaney, 'Organized out of politics? Parliamentary scrutiny of the substantive representation of women in UK governments' legislative programmes 1945-2012', Women's Studies International Forum, 50 (2015), pp. 57-67.

${ }^{71}$ Duncan Sutherland, 'Peeresses, parliament and prejudice: the admission of women to the House of Lords, 1918-1963', Parliaments, Estates and Representation, 20 (2000) pp. 215-32; Mari Takayanagi, 'A changing house: the Life Peerages Act 1958', Parliamentary History, 27 (2008), pp. 380-92.

${ }^{72}$ Peter Dorey and Alexandra Kelso, House of Lords reform since 1911: must the Lords go? (Basingstoke, 2011); Chris Ballinger, The House of Lords, 1911-2011: a century of non-reform (Oxford, 2012); Peter Raina, House of Lords reform: a history, III: 1960-1969: reforms attempted (Oxford, 2014). 
Norton has shown that the astute observer of the Palace of Westminster needs to go beyond Punch and Judy party politics to discover the moving parts of the British constitution. ${ }^{73}$ In Reform of the House of Lords Norton leads us around the upper chamber, walking the reader through the arguments for and against changing who gets to join the Lords and what they do once they are there. Norton points out that most nations prefer single-chamber legislatures, bicameralism being the preference of larger states or federal systems. Numerically, this may be true. However, a handful of honourable exceptions aside - in Scandinavia, Portugal, Greece, and New Zealand-most older parliamentary democracies favour two chambers, not one. ${ }^{74}$ The classic argument for their co-existence is that the second chamber or upper house allows for a different kind of representation than that afforded by the popularly elected lower house, and also means that legislation initiated in one chamber can be reviewed in the other. Norton demonstrates how the British House of Lords, especially in the last half-century, has been most adept in this latter function, not blocking but scrutinizing and improving the work of the Commons, an argument that is supported by the wider literature. ${ }^{75} \mathrm{He}$ also points out how, more recently, the traditional role of the House of Lords as a final court of appeal has been transformed by the 2005 legislation that established the Supreme Court as a separate institution (now housed in the Middlesex Guildhall), rather than a special function of the second chamber (that is, the "law lords'). ${ }^{76}$ As a house of 'reflection', then, Norton gives his second home a relatively clean bill of health. More might have been said about legislation that originates in the House of Lords, now less important than it used to be. However, Norton's is a short book, and if there is an overwhelming case for Lords reform, it relates to its composition and not to its work.

In modern times, the size of the Lords has developed out of all proportion to its operations. On the eve of Tony Blair's famous decimation of the hereditary element in 1999, there were twice as many peers as MPs. Along with the spaces set aside for royalty on state occasions, the Lords still occupies more of the site of parliament than the Commons. As Reform of the House of Lords documents, there has been no shortage of attempts to change the way the Lords is selected. Norton himself comes down on the side of the 'Wakeham' solution of a partly elected, partly appointed Lords, but this, like most other proposals since 1958, has been resisted by the Commons, fearful of any challenge to its democratic mandate. Indeed, House of Lords reform is stuck in a groove. The arguments for creating a more representative chamber without

\footnotetext{
${ }^{73}$ Philip Norton, Dissension in the House of Commons, 1945-1974 (London, 1975); idem, Governing Britain: parliament, ministers and our ambiguous constitution (Manchester, 2020).

${ }^{74}$ Russell, Reforming the House of Lords; Anthony Mughan and Samuel Patterson, eds., Senates: bicameralism in the contemporary world (Columbus, OH, 1999); Nicholas Baldwin and Donald Shell, eds., Second chambers (London, 2001); Richard Albert et al., eds., Constitutional reform of national legislatures: bicameralism under pressure (Cheltenham, 2019).

${ }^{75}$ Meg Russell, The contemporary House of Lords: Westminster bicameralism revived (Oxford, 2013).

${ }^{76}$ For the background, see Gavin Drewry, 'The UK Supreme Court: a fine new vintage, or just a smart new label on a dusty old bottle?', International Journal for Court Administration, 3 (2011), pp. 20 33; Louis Blom-Cooper et al., eds., The judicial House of Lords, 1876-2009 (Oxford, 2010).
} 
interfering with the Commons have not moved on very much since the nineteenth century. It was a mid-Victorian former prime minister-Lord John Russell - who in 1869 first mooted life peerages as a means of refreshing the Lords, which then numbered 467. And it was a late Victorian viceroy-to-be, George Curzon, who in 1888 called for the Lords to be reduced from 500 to 322 , comprising 200 hereditary peers who had already held public office, 50 life peers chosen by MPs, and 50 chosen by the crown, together with representatives from the colonies. Curzon likened his 'senate' to the upper houses of Italy, Spain, and Hungary. ${ }^{77}$ But the membership of the Lords went unchanged. And in the twentieth century, like an untreated illness, the problem spread and became more complex.

By the time the Life Peerages Act was passed in 1958, the Lords had swelled to over 800. Instead of setting a limit on the number of new life peers, as both Russell and Curzon had proposed, no ceiling was applied. In this way, since 1958 life peerages have become a means of immense government patronage. Whereas new peerage creations were few and far between in the nineteenth century, by the 1970s governments were using the device to bolster their advantage in the Lords. During Harold Wilson's second administration of 1974-6, there were eighty-three new life peerages, or one every nine days, a rate almost equalled by the governments of both Tony Blair and David Cameron. ${ }^{78}$ Thus, the problem of the composition of the House of Lords is a relatively recent one. Only since the 1970s has the executive come to dominate the Lords. This point is missed by most historians of Lords reform, who see Britain's upper chamber as a curious leftover from the Victorian and Edwardian era. In fact, whereas plenty has been written about the operations of the modern House of Lords (and its Hanoverian ancestor), how it worked in the half-century before the clipping of its wings in 1911 merits more research. ${ }^{79}$ The nineteenth- and early twentieth-century upper chamber was much smaller, it had a representative rationale, and it both initiated and amended legislation. Compared to its modern counterpart, it made more sense, and needs to be better understood by way of comparison. The historical proceedings of the Lords now inhabit the same digital universe as those of the Commons. There is no need for them to be neglected.

\section{VII}

In the last decade, it is not the Lords but the Commons that has been seen as most in need of reform. The parliamentary expenses scandal of 2009 engulfed

\footnotetext{
${ }^{77}$ HC Debs, 195 (27 Apr. 1869), cols. 1670-6; George N. Curzon, 'The reconstruction of the House of Lords', National Review, 11 (1888), pp. 153-75.

${ }^{78}$ www.peerages.info/admintable.htm. For peerage creation in the nineteenth century, see Michael W. McCahill, 'The new peerage: recruitment to the House of Lords, 1704-1847', Historical Journal, 46 (2003), pp. 1-38; Andrew Adonis, Making aristocracy work: the peerage and the political system in Britain, 1884-1914 (Oxford, 1993).

${ }^{79}$ The best work here is now over twenty-five years old: Adonis, Making aristocracy work; Richard W. Davis, ed., Lords of parliament: studies, 1714-1914 (Stanford, CA, 1995); Corinne Comstock Weston, The House of Lords and ideological politics: Lord Salisbury's referendal theory and the Conservative Party, 1846-1922 (Philadelphia, PA, 1995).
} 
both houses of parliament, resulted in the imprisonment of five MPs and two peers and the resignation of the Commons Speaker. The scandal also killed off Prime Minister Gordon Brown's chances of returning for a second term of office in 2010. Emma Crewe and Andrew Walker's account of the episode is the best yet. ${ }^{80}$ An extraordinary scandal combines an insider's account (Walker worked in the Fees Office in parliament) with an anthropologist's insights on how people behave in institutional contexts, a skill which Crewe has already put to good use in two highly original studies of parliamentarians. ${ }^{81}$ Combining interviews (mainly anonymous) with those caught up in the scandal together with a close reconstruction of events, Crewe and Walker document how parliament came to be seen as public enemy number one.

Historically and compared to other countries, MPs in Britain have never been well paid. By the 1970s and 1980s, the disparity between the salaries of MPs and those of other professions had grown significantly. ${ }^{82}$ Rather than hike up MPs' pay at a time when belts were being tightened in the public sector, parliament extended the system of 'Additional cost Allowances' to cover a whole range of out-goings associated with residing both in London and in the MPs' constituency. In theory, MPs at the turn of the millennium could command a gross parliamentary income of $£ 160,000$ should they have chosen to compound their take home pay with their allowance. ACAs were lightly regulated by the parliament's Fees Office. Without slipping into investigative Watergate-style journalism, Crewe and Walker vividly capture the slowburning drama that unfolded. They describe how the ingredients of a perfect storm' fell into place. Indefatigable reporters pounced on the Freedom of Information Act of 2000 to probe into parliamentary accounting. Then in 2007 , in one of its final acts, Tony Blair's government supported a review that recommended a significant increase in MPs' salaries and allowances. By the early summer of 2008, the persistence of the journalists paid off. The High Court ruled that all the relevant records must be released, just as the financial crisis of the autumn of 2008 broke. In April 2009, The Daily Telegraph secured a complete unredacted version of all the expenses claims, and for the next few months revelations about the dubious doings of MPs flooded the media.

An extraordinary scandal is sympathetic in tone. The authors intend neither an attack nor a defence of the culture of the Commons. Parliament does emerge as not only uncooperative, but also blind to the wider public mood, particularly once the recession kicked in. At the same time, Crewe and Walker are wary of a 'cartoon version' of MPs simply in it for themselves (that does not stop them including cartoons that reproduce such stereotypes). They offer some larger explanations of why the expenses affair tipped out of

\footnotetext{
${ }^{80}$ See also Robert Winnett and Gordon Rayner, No expenses spared (London, 2009), written by The Daily Telegraph team who exposed all the details; Jennifer Van Heerde-Hudson, ed., The political costs of the 2009 British MPs' expenses scandal (Basingstoke, 2014).

${ }^{81}$ Emma Crewe, Lords of parliament: manners, rituals and politics (Manchester, 2005); idem, The House of Commons: an anthropology of MPs' work (London, 2015).

${ }^{82}$ For some historical background, see Edward Hicks, 'MPs' pay: the never-ending controversy' (2013), https://thehistoryofparliament.wordpress.com/2013/12/09/mps-pay-the-never-ending-controversy/.
} 
control. In modern times, they suggest, MPs are more under the spotlight, with less deference shown towards public figures. Echoing older work on 'the rise of the career politician', they point out that parliament is more of a vocation nowadays than a pro bono service, yet it has not been remunerated as such. ${ }^{83}$ And they argue that the electorate hold unrealistic expectations of their MPs, assuming they are no different from anyone else, but also holding them to higher standard of probity. The expenses scandal, An extraordinary scandal concludes, simply caught out MPs who "were mainly guilty of ordinarily trying to do a decent job and in many cases getting into a spectacular ethical muddle'. Above all, they stress reassuringly, 'examples of corruption in the last one hundred years are relatively rare'.

At one level, this is incontestable. The Victorians did a good job of cleansing the Commons of 'old corruption', mainly by clamping down on malpractice at elections. ${ }^{84}$ They made it easier for the poor but worthy to enter parliament by abolishing the property qualification in 1858 , and they rid parliament of the rich and feckless by barring bankrupts in $1871 .^{85}$ They also inherited a long list of people not eligible to stand for parliament. Even the encyclopaedic Erskine May complained of there being far too many 'special disqualifications' to enumerate, most of them connected with holding an office of profit under the crown. ${ }^{86}$ By convention, MPs were also supposed to refrain from involvement in any parliamentary business in which they had a 'pecuniary' interest, and by an act of 1782 they were also prevented from being government contractors. However, there was never any compulsion to declare possible conflicts of interest or patronage, besides the inconvenience until 1926 of having to stand for re-election if appointed to ministerial office. Parliament policed itself throughout the nineteenth and twentieth centuries, only relinquishing one of its judicial roles, the trial of controverted elections, to the courts (in 1868). The archaic rules on disqualification and contracting were not modernized until 1957. There was no listing of MPs' outside interests until an informal 'register' was introduced in $1974 .^{87}$

\footnotetext{
${ }^{83}$ Anthony King, 'The rise of the career politician and its consequences', British Journal of Political Science, 11 (1981), pp. 249-85; S. J. Henn, 'The further rise of the career politician', British Politics, 13 (2018), pp. 524-53. See also Michael Rush, The role of the member of parliament since 1868: from gentlemen to players (Oxford, 2001).

${ }^{84}$ Cornelius O'Leary, The elimination of corrupt practices in British elections, 1868-1911 (Oxford, 1962); William B. Gwyn, Democracy and the cost of elections (London, 1962); Michael Dawson, 'Money and the real impact of the Fourth Reform Act', Historical Journal, 35 (1992), pp. 369-81; Kathryn Rix, “'The elimination of corrupt practices in British elections"?: reassessing the impact of the 1883 Corrupt Practices Act', English Historical Review, 123 (2008), pp. 65-97; Paul Seaward, 'Old corruption and parliamentary reform: an historical perspective on the current crisis', Political Quarterly, 81 (2010), pp. 39-48.

${ }^{85}$ On the property qualification, the standard account remains Helen Witmer, The property qualifications of members of parliament (New York, 1943). For bankruptcy law reform, see John Tribe, 'Parliamentarians and bankruptcy: the disqualification of MPs and peers from sitting in the Palace of Westminster', King's Law Journal, 25 (2014), pp. 79-101.

${ }^{86}$ May, Treatise (9th edn, London, 1883), p. 34n.

${ }^{87}$ For some of the background, see Richard Kelly et al., 'The law and conduct of members of parliament', in Alexander Horne and Gavin Drewry, eds., Parliament and the law (2nd edn, Oxford,
} 
In other words, historians are not in a position to say as yet whether MPs always followed the public interest ahead of their own. The limited research that has been undertaken on, for example, MPs and railway companies in the 1840s, or MPs with banking backgrounds in the 1880 s and 1890 s, reveals examples of what would now be called 'insider trading' or 'log-rolling' ${ }^{88} \mathrm{We}$ also know from other datasets and longitudinal studies that MPs with direct links to slavery and to large landed estates featured in parliament over several generations, and that single families monopolized the representation of some constituencies across three centuries. ${ }^{89}$ The motive for private enrichment at public expense certainly existed, but were the opportunities taken? Moreover, the conventions of virtual representation demanded that members of parliament had close connections with the 'interests' that they represented. None of this means that corruption has a long history. Rather, it shows that more detailed analysis of MPs' networks and their personal assets across the nineteenth and twentieth centuries is necessary.

\section{VIII}

With the 2016 Brexit referendum, Britain seemed to put parliamentary representation on hold. Not only did parliament defer to the electorate in mandating the UK government over the future of Britain's membership of the European Union, but throughout the drawn-out discussions over the terms of Britain's withdrawal, parliament had to fight for its right to deliberate, requiring two rulings by the Supreme Court to ensure that MPs and peers had their say. ${ }^{90}$ The Brexit crisis raised fundamental issues about where sovereignty lies in the British constitution, at what point direct democracy trumps delegated representation. Although not lacking a history of its own, the referendum in British politics has always seemed a marginal cause. ${ }^{91}$ Now it has

2018), pp. 43-72. On ministerial by-elections, see Martin Pugh, “"Queen Anne is dead”: the abolition of ministerial by-elections, 1867-1926', Parliamentary History, 21 (2002), pp. 351-66; Angus Hawkins, 'Government appointment by-elections: 1832-1886', in T. G. Otte and P. Readman. eds., By-elections in British politics, 1832-1914 (Woodbridge, 2013), pp. 51-76.

${ }^{88}$ Y. Cassis, 'Bankers in English society in the late nineteenth century', Economic History Review, 38 (1985), pp. 210-29; Rui Esteves and Gabriel Geisler Mesevage, The rise of new corruption: British MPs during the railway mania of 1845, Centre for Economic Policy Research Discussion Paper 12182 (London, 2017). See also Alex S. Rosser, 'Businessmen in the parliament of 1852-1857: players or spectators?', Parliamentary History, 32 (2013), pp. 477-505.

89490 MPs have been identified by the 'Legacies of British slavery' project: www.ucl.ac.uk/lbs/ political/. For landowners, see David F. Krein, 'The great landowners in the House of Commons, 1833-1885', Parliamentary History, 32 (2013), pp. 460-76. For families, see E. A. Wasson, 'The House of Commons, 1660-1945: parliamentary families and the political elite', English Historical Review, 106 (1991), pp. 635-51.

${ }^{90}$ M. Elliott et al., eds., The UK constitution after Miller: Brexit and beyond (London, 2018); Petra Schleiter and Thomas G. Fleming, 'Parliamentary prorogation in comparative context', Political Quarterly, 91 (2020), pp. 641-8.

${ }^{91}$ It is significant that it has taken the Brexit moment to produce the first substantial histories of the 1975 referendum: Robert Saunders, Yes to Europe!: the 1975 referendum and seventies Britain (Cambridge, 2018); and Lindsay Aqui, The first referendum: reassessing Britain's entry to Europe, 1973- 
entered centre-stage. A new genre of academic punditry-a kind of 'Brexpertise' - has emerged to explain the crisis, particularly its constitutional aspects. ${ }^{92}$ Two recent examples are Matt Qvortrup's collection of essays on referendums across history and around the world, and Andrew Blick's monograph, an insider's account of the Brexit crisis combined with a review of blueprints for constitutional reform across the twentieth and early twenty-first centuries.

Qvortrup observes that although 'Europe is clearly in the grip of a sort of referendum mania', referendums have a long history. He goes as far to dig out some from mid-sixteenth-century France, although the evidence is scanty. His book is on firmer ground in its description of the plebiscitary democracies that emerged in the new republics of France and the USA, but even here he skates over the citizens' initiatives built into the constitutions of individual states such as Massachusetts, Kansas, and California. In the twentieth century, authoritarian regimes briefly appropriated the plebiscite. But Qvortrup shows how since the Second World War the referendum has become a common device in a variety of political situations. He offers some pertinent case-studies, such as Switzerland, and the long list of referendums in EU member states since 1972. Despite drawing on a large global dataset, there are some gaps. India has had six referendums since 1947, but none of them are mentioned, nor are any of the referendums that accompanied independence in other parts of the Commonwealth in the 1950s and 1960s. ${ }^{93}$ And for all the breadth of knowledge on display, Qvortrup's conclusions are lightweight. Brexit was a rational choice: people wanted sovereignty more than economic security. The rage for referendums, he suggests, reflects both populism and partisan dealignment (i.e. a more volatile electorate). Referendums are welcome as a dose of direct democracy, we are told, but beware 'cynical' politicians who use them to their advantage.

1975 (Manchester, 2020). For the referendum in Britain in a longer historical perspective, see Vernon Bogdanor, The people and the party system: the referendum and electoral reform in British politics (Cambridge, 1981); J. Meadowcroft and Michael W. Taylor, 'Liberalism and the referendum in British political thought, 1890-1914', Twentieth Century British History, 1 (1990), pp. 35-57; Logie Barrow and Ian Bullock, Democratic ideas and the British labour movement, 1880-1914 (Cambridge, 1996), pp. 39, 52; Mads Qvortrup, 'A. V. Dicey: the referendum as the people's veto', History of Political Thought, 20 (1999), pp. 531-46; Miles Taylor, 'Brexit and the British constitution: a long view', Political Quarterly, 90 (2019), pp. 719-26; Lucy Atkinson, Andrew Blick, and Matt Qvortrup, The referendum in Britain: a history (Oxford, 2020).

${ }^{92}$ Vernon Bogdanor, Beyond Brexit: towards a British constitution (London, 2019); Roundtable: contemporary European historians on Brexit, special issue, Contemporary European History, 28 (2019); Jim McConalogue, The British constitution resettled: parliamentary sovereignty before and after Brexit (London, 2019); Diane Fromage and Thomas Christiansen, eds., Brexit and democracy: the role of parliaments in the UK and the European Union (London, 2019).

${ }^{93}$ Shoaib Daniyal, 'With Brexit a reality, a look back at six Indian referendums (and one that never happened)', 24 June 2016, https://scroll.in/article/810564/with-brexit-a-reality-a-look-back-at-sixindian-referendums-and-one-that-never-happened; Thomas B. Smith, 'Referendum politics in Asia', Asian Survey, 26 (1986), pp. 793-814; Klaas van Walraven, 'Decolonization by referendum: the anomaly of Niger and the Fall of Sawaba, 1958-1959', Journal of African History, 50 (2009), pp. 269-92. 
Stretching the constitution is a more substantial account of Brexit and its effects on parliament and other parts of the British political system. Blick likens Brexit to a 'shock', a term normally used by economists or earth scientists to explain irreversible structural change, although here the analogy is to a 'self-inflicted wound', like sticking a finger in a plug-socket. The first part of the book offers a detailed reconstruction of the Brexit debates in parliament before and after the Brexit vote. Blick draws on his own experiences in the Prime Minister's Office in 1999 and as a Commons researcher a decade or so later. A diligent sifter of statutes, committees, and memoranda (several of which are reproduced in the volume), he concludes that parliament went ahead with the referendum without 'sufficient attention being devoted to its constitutional aspects'. These included, amongst others, its different impact across the four nations of the UK, free-for-all 'remain' and 'leave' campaigns that did not abide by the same rules as normal elections, and the confusion over whether the referendum result would be binding or subject to further consideration by parliament. The moral of the story is a familiar one: Brexit has exposed the fatal consequences of Britain lacking a written constitution.

In the rest of his book, Blick attempts to make good this deficiency by providing a digest of over a century of attempted reforms of the Westminster model: a constitution-in-waiting as it were. The parade of proposals includes most of the great and good: the Webbs on a 'socialist commonwealth', John St Loe Strachey on the referendum, Harold Laski on a more expert civil service, Bernard Crick on specialist committees and improved parliamentary research services, John Mackintosh on devolution, and Ivor Jennings on a European 'federal union'. There are some odd choices too. Edward Goldsmith, the ecologist, is in, but not his younger brother James, whose Referendum party of the early 1990s was a key catalyst in the road to Brexit. There is Anthony Barnett's scheme of Lords Reform of 1999, but not the much more influential Charter 88 (of which Barnett was a founding member). Winston Churchill's suggestion of an 'economic sub-parliament' in June 1930 is discussed, without reference to Oswald Mosley's controversial plan for corporate government outlined earlier that same year. Room is found for H. G. Wells and Tony Benn on technology and constitutional innovation, but no space is given to the Speaker's Conference on Digital Democracy which reported in 2015 and which has already reaped dividends (for example, free online access to Hansard).

It is unclear how any of these proposals would have saved Britain from the 'shock' of Brexit. Few of the federal schemes outlined in Stretching the constitution would have interfered with the sovereignty of the Westminster parliament in the same way as membership of the European Union. Most of the proposals for referendums aimed at responding to legislation, not initiating it, as Brexit did. Many of the elaborate schemes for electoral reform described here were advocated during wartime, when normal democracy was suspended and inventive minds could dream of utopian solutions. Finally, the piecemeal tradition of procedural reform of the Commons and Lords recommended by Blick - for example, specialist standing committees, improved information services - is one that has always been within the capacity of 
parliament to implement, as the case-studies in the Erskine May volume attest.

One problem with parliamentary democracy that Blick's book is right to foreground is the creeping power of the executive. The Victorians convinced themselves that theirs was a 'parliamentary government'. By the 1930s, that boast seemed hollow, and Laski and others lamented its demise. 'Cabinet government' seemed more apposite by the 1950s, to be superseded by 'prime ministerial government' in the early 1970s, before that too became redefined as the 'presidentialization' of the premiership twenty years later, around the time that Tony Blair came to power. ${ }^{94}$ Here perhaps lies the real the shock of Brexit. As Blick notes, it was New Labour's Political Parties, Elections, and Referendums Act of 2000 that laid the foundations for the Brexit vote. No mention was made in that act about the role of parliament, nor was anything said about whether the outcome of the referendum would be binding. However, the advice given to Blair by the act's architect, Lord Nairne, was clear, and reflected the same course of action taken in the earlier vote on British membership of the European Economic Community in 1975. The fate of the referendum lay in the hands of the government of the day, with or without the consent of parliament. ${ }^{95}$ The executive would decide. As Qvortrup points out, most governments win referendums of which they are the master. Brexit turned out differently, but the moral was the same. Not so much the triumph of the people's will over their elected representatives, as the reassertion of executive control over the legislature. As the UK battles against the pandemic, that control has been extended through the introduction of emergency powers usually reserved for wartime (the Coronavirus Act), a development repeated elsewhere across Europe and beyond. ${ }^{96}$ Two centuries on from the emergence of legislative democracy around the world, much has changed, but the struggle over where sovereign power lies remains.

\section{IX}

Whilst the future of parliament is unclear, amidst the twin-shocks of Brexit and the pandemic, the history of parliamentary representation in the modern era is in good shape. We now know more about individual MPs and constituencies than ever before. The digitization of the records of parliament is expediting the kind of longitudinal analysis which was impossible back in the 1960s and 1970s. And the intellectual history and public policy literature around the idea of representation is enjoying a renaissance. Older interpretive paradigms

\footnotetext{
${ }^{94}$ Bruce Lenman, The eclipse of parliament: appearance and reality in British politics since 1914 (London, 1992); Michael Foley, The rise of the British presidency (Manchester, 1993); Sue Pryce, Presidentializing the premiership: the prime ministerial advisory system and the constitution (Basingstoke, 1997); Mark Bevir and R. A. W. Rhodes, Governance stories (Abingdon, 2006), ch. 6.

${ }^{95}$ Report of the commission on the conduct of referendums, 'The Nairne report' (21 Nov. 1996), pp. 27, 43, www.ucl.ac.uk/constitution-unit/sites/constitution-unit/files/7.pdf.

${ }^{96}$ Krisztina Binder et al., States of emergency in response to the coronavirus crisis: situation in certain member states (Brussels, 2020), www.europarl.europa.eu/RegData/etudes/BRIE/2020/649408/EPRS BRI(2020)649408_EN.pdf; Alan Greene, Emergency powers in a time of pandemic (Bristol, 2020), ch. 4.
} 
still lurk, especially an obsession with 'democratization'. There is also a tendency to view parliament mainly as an arena of partisanship rather than a legislative institution; and an insular prejudice that sets the British experience apart from the rest of Europe. In their different ways, these ten volumes show a discipline in a state of healthy flux, ripe and ready both for a new generation of research and a new synthesis of approach.

Cite this article: Taylor M (2022). Parliamentary Representation in Modern Britain: Past, Present, and Future. The Historical Journal 65, 1145-1173. https://doi.org/10.1017/S0018246X2100073X 